\title{
The microbiology contaminants and microclimate parameters in the nursery building
}

\author{
E. Zender-Świercz ${ }^{1}$ (1) $\cdot$ M. Telejko² $\cdot$ M. Starzomska $\cdot$ A. Łubek $^{3}$
}

Received: 5 November 2018 / Revised: 25 January 2019 / Accepted: 18 February 2019 / Published online: 28 February 2019

(c) The Author(s) 2019

\begin{abstract}
The indoor microclimate quality is an important factor affecting the human body. Inappropriate microclimate parameters and air pollutants can cause health problems or even be life-threatening. In addition, it can reduce work productivity and learning efficiency. In the article, the analysis of the rooms in the nursery building ventilated by a mechanical system equipped with air ionizers was conducted. The results of research were compared with the research results for rooms of the same type, but equipped with the passive stack ventilation. Fungi were detected in the analyzed building that does not pose a threat to the lives of people, but they can cause allergies and asthma. With regard to the reference objects, in the analyzed building, the microclimate was free from fungi species yeast-like fungi and Trichoderma viride, which occurred in the reference rooms. The indoor relative humidity was kept at a level not conducive to the development of fungi. The concentration of the carbon dioxide in rooms where children stayed permanently did not exceed the permissible value. Slight excessive concentration levels were observed only in the cloakroom. Only the internal air temperature exceeded $25^{\circ} \mathrm{C}$, which favors the development of fungi. This means that it would be appropriate to lower the indoor air temperature.
\end{abstract}

Keywords Air quality $\cdot$ Building ventilation $\cdot$ Carbon dioxide concentration $\cdot$ Microbiological contaminant

\section{Introduction}

The microclimate quality in rooms is primarily its composition. The internal air is a mixture of dry air and moisture. The acceptable indoor air quality, in accordance with the standard ASHRAE 2016, is defined as "air in which there are no known contaminants at harmful concentrations as determined by cognizant authorities and with which a substantial majority ( $80 \%$ or more) of the people exposed do not express dissatisfaction".

Editorial responsibility: M.Abbaspour.

E. Zender-Świercz

ezender@tu.kielce.pl

1 Geomatic and Energy Engineering, Department of Building Physics and Renewable Energy, Faculty of Environmental, Kielce University of Technology, Kielce, Poland

2 Department of Technology and Building Organizations, Faculty of Civil Engineering and Architecture, Kielce University of Technology, Kielce, Poland

3 Institute of Biology, Jan Kochanowski University, Kielce, Poland
The importance of the air quality as a threat to public health changes significantly depending on the level of development of a given country. In the developing countries, where mortality is high due to the various diseases, the pollution of the air contributes to 3.7\% of disease burden. At the same time, the same factor is not mentioned in the top of 10 leading pathogens in developed countries (Miskiewicz 2005).

The poor air quality affects reducing the work efficiency and increasing the frequency of employees' sickness. In the case of schools, it reduces the efficiency of learning, what was described in the literature (Sowa 2017; Telejko and ZenderSwiercz 2017; Wargocki and Wyon 2006; Bakó-Biró et al. 2012). The poor air quality mostly is from insufficient air exchange in rooms, which in turn may be a result of airtightness of building (Nantka 2006). Because of children's susceptibleness to poor indoor air quality (Schwartz 2004), the Children's Environment and Health Action Plan for Europe (CEHAPE) (WHO 2004) expresses the need for developing indoor air quality strategies taking into account the specific needs of children.

Very important pollution is the reactive oxygen species which was described in Khurshid et al. (2014). But the other 
important pollution of the internal environment is the fragments of fungi and molds released from the surface on which they have developed. According to researchers' analysis (Górny 2005; Fisk et al. 2007; Mendell et al. 2011), they are significantly biologically harmful due to the immunological reactivity, the cytotoxicity or the mycotoxin transport. The potential harmfulness of microbial contamination is dependent on the species content and concurrently occurring species combinations, as well as on the material and growth conditions in which the microbial proliferation occurred (Garrett et al. 1998; Huttunen et al. 2004; Penttinen et al. 2006; Samson et al. 1994; Tuomi et al. 2000).

A significant pollutant in the premises for people is carbon dioxide (CO2). It is a gas that is exhaled by people, and at the same time, it constitutes the pollution of air. It is odorless and easy to measure. Moreover, intensity of its generation by people is very well correlated with emission of human bioeffluents (having unpleasant odor and difficult to measure). Because of this, $\mathrm{CO} 2$ is commonly used as an IAQ indicator.

The analysis covered the nursery building located in the city in the temperate climate in the third climatic zone. The study was conducted over the years 2016-2017. For the analysis, data from the winter months, i.e., December, January, February, were selected.

\section{Materials and methods}

The analysis included the nursery building equipped with the mechanical ventilation system. The measurements were carried out in the rooms: playroom, children's bedroom, cloakroom and dining room (Table 1 ).

Fifteen children and two teachers were in the rooms. The air was supplied and exhausted in an organized way by three air-handling units equipped with air ionizers. The ventilation system was also used to heat the rooms. In the toilets, the air heating was supported by a floor system powered by a heat pump. The heat pump also delivered heat to the heaters in the air-handling units.

The microbiological research was carried out in two series using the breeding method. The agar Sabouraud with

Table 1 Data of analyzed rooms

\begin{tabular}{llcl}
\hline The room & $\begin{array}{l}\text { Floor area of } \\
\text { room }\left[\mathrm{m}^{2}\right]\end{array}$ & $\begin{array}{l}\text { Volume of } \\
\text { room }\left[\mathrm{m}^{3}\right]\end{array}$ & $\begin{array}{l}\text { Ventila- } \\
\text { tion rate } \\
{\left[\mathrm{h}^{-1}\right]}\end{array}$ \\
\hline Playroom & 47.75 & 145.64 & 2 \\
Children's bedroom & 47.44 & 144.96 & 1.7 \\
Cloakroom & 20.07 & 61.21 & 4 \\
Dining room & 15.94 & 48.62 & 1.2 \\
\hline
\end{tabular}

$4 \%$ glucose addition was used for the analysis. The determination of fungi took place after the incubation period at $25^{\circ} \mathrm{C}$ in the first series and $37^{\circ} \mathrm{C}$ in the second series. The sedimentation method, which was used, has the disadvantages, such as lack of knowledge of the referencing volume of the air and the inability to detect the finest particles settling very slowly. Because of it, this method served only to compare the observed fungi in the air in the analyzed rooms with reference rooms.

In both series, the exposure time for the open petri dishes was $10 \mathrm{~min}$.

The study of the internal microclimate parameters was carried out in four series. The air quality monitor was used to carry out the measurements. Its measuring ranges are presented in Table 2. The concentration of carbon dioxide, temperature and air humidity was analyzed in the rooms. The $\mathrm{CO} 2$ concentration was measured using a double-beam detector which uses a dependence of attenuation, a specific band of infrared radiation from the carbon dioxide concentration. Temperature and relative humidity were measured with miniature semiconductor sensor.

The indoor microclimate parameters were measured continuously in two-week periods with the registration of results at intervals of $10 \mathrm{~min}$.

The analysis was carried out in the autumn and the winter period at the turn of 2016-2017.

\section{Results and discussion}

\section{Microbiological analysis}

A qualitative analysis of the obtained results of the microbiological tests was carried out. The species of the incubated fungi were determined, and their list is presented in Tables 3 and 4 . Depending on the incubation temperature, the various fungal species were observed.

For both incubation temperatures, the fungi of species Botrytis sp. were observed (Fig. 1). It was both in the external and the internal air. The room in which the least fungi were observed was a bedroom, i.e., a room where the duration of children's presence was the shortest. The largest number of observed fungi was observed in the playroom, i.e.,

Table 2 Measuring ranges and accuracy of indoor air quality monitor display

\begin{tabular}{llll}
\hline Parameter & Measuring ranges & Accuracy & Unit \\
\hline $\mathrm{CO}_{2}$ concentration & $0-5000$ & 1 & $\mathrm{ppm}$ \\
Relative humidity & $0-100$ & 0.1 & $\%$ \\
Air temperature & $10-45$ & 0.1 & ${ }^{\circ} \mathrm{C}$ \\
Barometric pressure & $900-1100$ & 1 & $\mathrm{hPa}$ \\
\hline
\end{tabular}


Table 3 The list of fungi's species incubated at the incubation temperature of $25^{\circ} \mathrm{C}$

Table 4 The list of fungi's species incubated at the incubation temperature of $37^{\circ} \mathrm{C}$

\begin{tabular}{|c|c|c|c|c|c|}
\hline Fungi species & External air & Playroom & Bedroom & Cloakroom & Dining room \\
\hline Chrysosporium sp. & + & & & & \\
\hline Botrytis sp. & + & & & & + \\
\hline Aureobasidium sp. & + & & & & \\
\hline \multicolumn{6}{|l|}{ Geotrichum sp. } \\
\hline Fusarium sp. & & & & & + \\
\hline Cladosporium sp. & & & & & + \\
\hline Candida sp. & & + & & + & \\
\hline Penicillium sp. & & + & & & \\
\hline \multicolumn{6}{|l|}{ Aspergillus sp. } \\
\hline Yeasts & & & + & + & \\
\hline \multicolumn{6}{|l|}{ Yeast-like fungi } \\
\hline Trichoderma viride & & & & & \\
\hline
\end{tabular}

\begin{tabular}{|c|c|c|c|c|c|}
\hline Fungi species & External air & Playroom & Bedroom & Cloakroom & Dining room \\
\hline Chrysosporium sp. & + & & & & \\
\hline Botrytis sp. & + & + & & + & + \\
\hline Aureobasidium sp. & + & & & & \\
\hline \multicolumn{6}{|l|}{ Geotrichum sp. } \\
\hline \multicolumn{6}{|l|}{ Fusarium sp. } \\
\hline \multicolumn{6}{|l|}{ Cladosporium sp. } \\
\hline \multicolumn{6}{|l|}{ Candida sp. } \\
\hline Penicillium sp. & & + & & & + \\
\hline Aspergillus sp. & & + & & + & \\
\hline Sordaria sp. & & + & & + & + \\
\hline Sepedonium sp. & & & & + & \\
\hline Alternaria sp. & & + & & + & \\
\hline Yeasts & & + & & & \\
\hline \multicolumn{6}{|l|}{ Yeast-like fungi } \\
\hline Trichoderma viride & & & & & \\
\hline
\end{tabular}

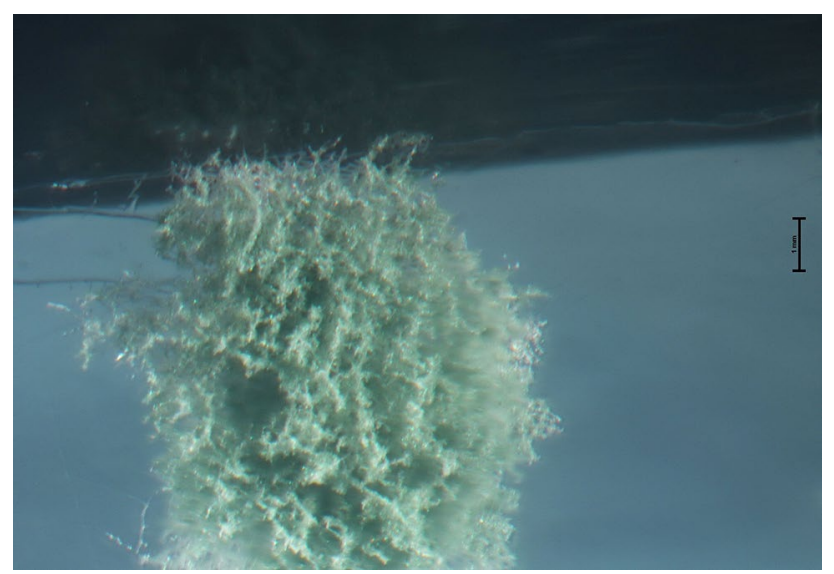

Fig. 1 The observed fungi from the species Botrytis sp. the place where children spent the most time. At the same time, the increased number of observed fungi's species did not occur at the incubation temperature of $25{ }^{\circ} \mathrm{C}$, i.e., the temperature of the internal air. Moreover, none of the species observed in the outdoor air was present in the rooms, so the supply air was sufficiently cleaned. It is worth noting that the observed fungi belonged to the species that are commonly found inside rooms, and their occurrence is associated with higher internal temperature. In the air at the temperature of about $20{ }^{\circ} \mathrm{C}$, these fungi's species are the least, while according to Fig. 3, the temperature in the analyzed rooms was much higher.

The obtained results were referred to the buildings of the same type equipped with the passive stack ventilation. Those buildings were presented in the literature (Koruba et al. 
Table 5 The list of fungi's species observed in building equipped with the passive stack ventilation

\begin{tabular}{|c|c|c|}
\hline Fungi species & Kindergarten I & Kindergarten II \\
\hline \multicolumn{3}{|l|}{ Chrysosporium sp. } \\
\hline \multicolumn{3}{|l|}{ Botrytis sp. } \\
\hline \multicolumn{3}{|l|}{ Aureobasidium sp. } \\
\hline \multicolumn{3}{|l|}{ Geotrichum sp. } \\
\hline \multicolumn{3}{|l|}{ Fusarium sp. } \\
\hline Cladosporium sp. & + & + \\
\hline \multicolumn{3}{|l|}{ Candida sp. } \\
\hline Penicillium sp. & + & + \\
\hline Aspergillus sp. & + & + \\
\hline \multicolumn{3}{|l|}{ Sordaria sp. } \\
\hline \multicolumn{3}{|l|}{ Sepedonium sp. } \\
\hline \multicolumn{3}{|l|}{ Alternaria sp. } \\
\hline Yeasts & & + \\
\hline Yeast-like fungi & + & \\
\hline Trichoderma viride & + & + \\
\hline
\end{tabular}

2014; Telejko and Zender-Swiercz 2016). The observed fungi's species were listed in Table 5.

The fungi of the species yeast-like fungi and Trichoderma viride in the building equipped with the mechanical ventilation were not observed. Those species of fungi were noted in buildings equipped with the passive stack ventilation, and they came from the outside air. The fungi of the species Cladosporium sp., Penicillium sp. and Aspergillus sp. were noted in all buildings (Fig. 2).

\section{Indoor microclimate parameters analysis}

The measurements of the indoor air temperature and humidity and also the concentration of carbon dioxide in indoor air were carried out. The obtained results of the measurements are presented in Figs. 3, 4 and 5 as average values for subsequent hours of the day.

The average temperature inside the rooms, where children were staying, i.e., in the playroom and in the bedroom,
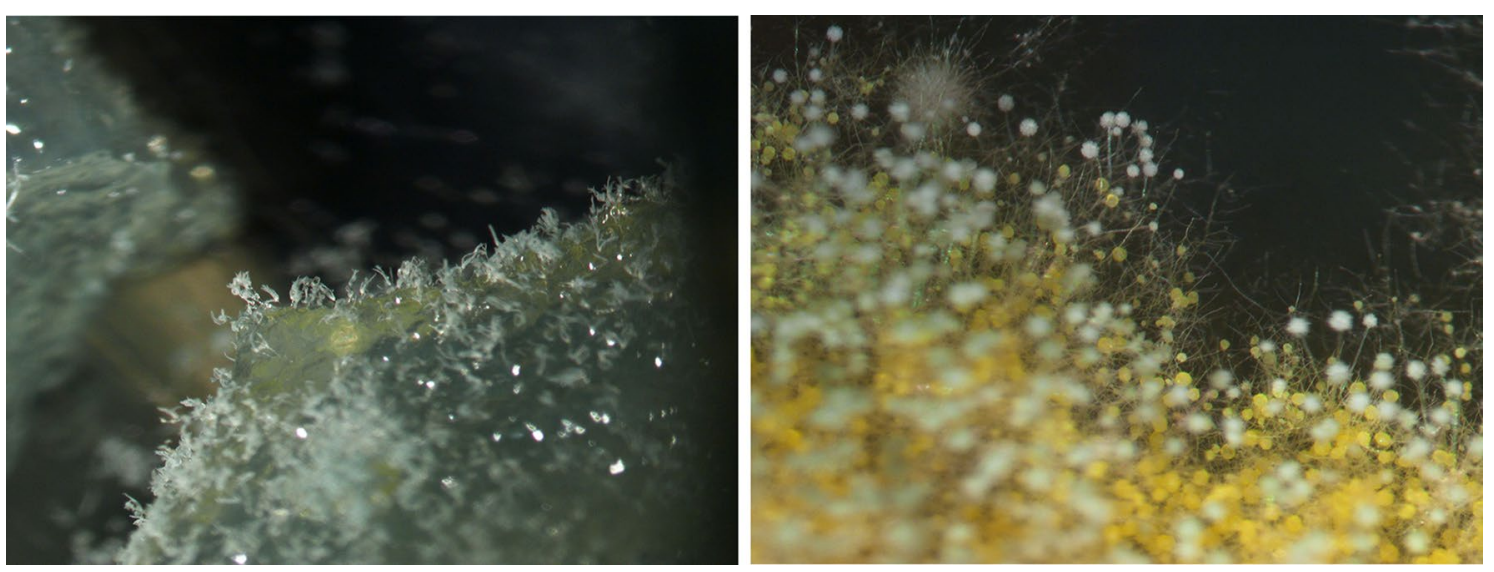

Fig. 2 The observed fungi from the species Penicillium sp. and Aspergillus sp.

Fig. 3 The indoor temperature versus time

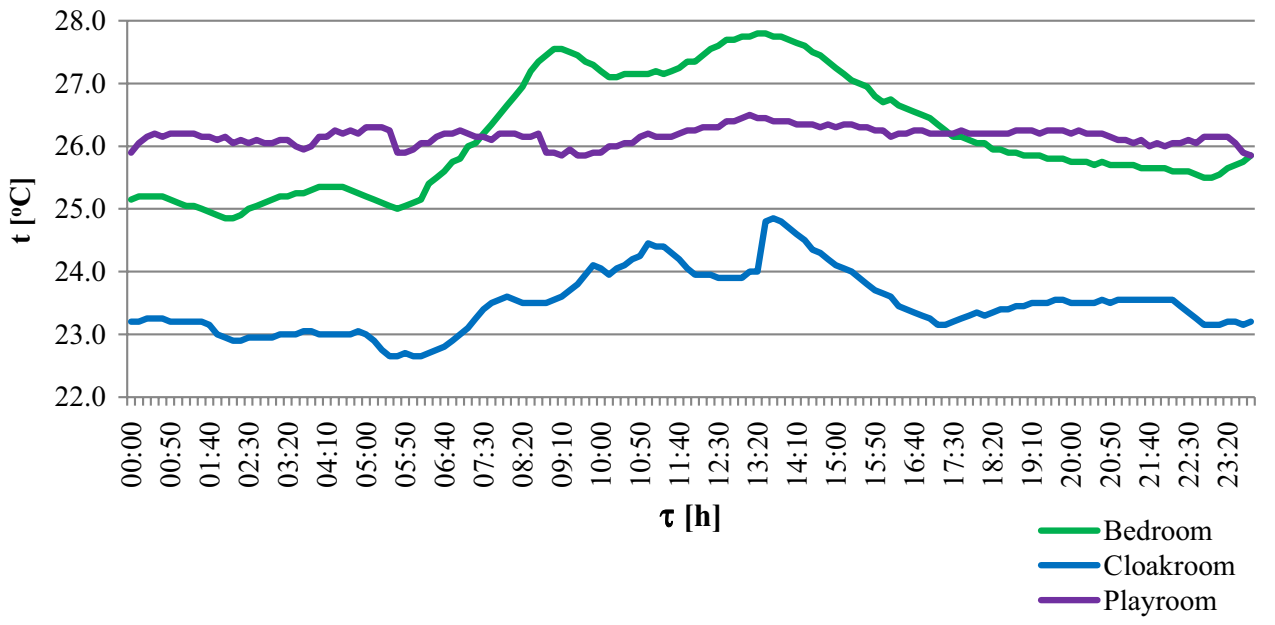


Fig. 4 The carbon dioxide concentration versus time
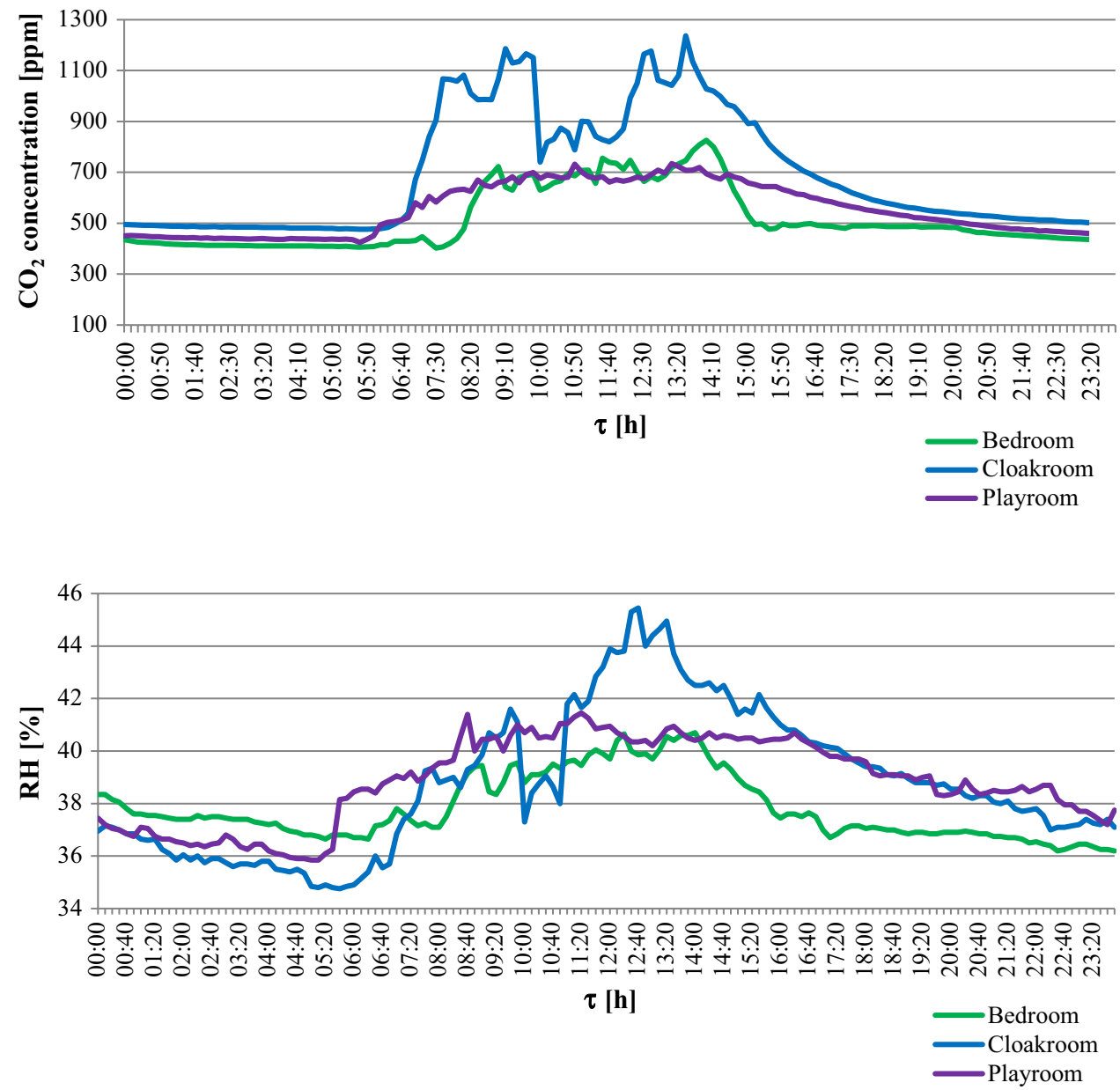

Fig. 5 The indoor air relative humidity versus time fluctuated within limits $24.9-27.8{ }^{\circ} \mathrm{C}$. The lowest values were recorded in the cloakroom $22.7-24.9^{\circ} \mathrm{C}$.

Such temperature values favor the development of mold fungi in the rooms. Therefore, the observed fungi in the playroom can be the result of too high temperature. The cloakroom is a room where people come from outside, the children leave their clothes (jackets, shoes), which is probably a source of microbiological contamination.

The recorded values of carbon dioxide concentration only in the cloakroom exceeded the permissible value of $700 \mathrm{ppm}$ above the concentration in the outdoor air. The permissible value was specified in ASHRAE 2016. In the rooms where children were permanently present, the values of $\mathrm{CO}_{2}$ concentration fluctuated within limits 202-826 ppm. This means that the air exchange in rooms where people are the main source of pollution is sufficient to dilute the pollutants. Regarding the influence of carbon dioxide on human health, the authors wrote in Zhang et al. (2017).

The analysis of the changes of the relative humidity in time has shown that the value of the parameter throughout the entire $24-\mathrm{h}$ period varies in the permissible range, i.e., $30-70 \%$. The highest recorded value was $45 \%$, and the lowest recorded value was $41 \%$. The relative humidity of the indoor air did not contribute to the development of fungi, because their development is intensifying at the air humidity of $60 \%$.

\section{Statistical methods}

The course of the temperature changes in the playroom was linear and almost constant; the parameter oscillated around the value of $26.1^{\circ} \mathrm{C}$. In the cloakroom and the bedroom, the temperature had a polynomial trendline. The highest observed values occurred during the day. At night, they were the lowest. This is due to the presence of children and teachers during daylight hours and because of the reduction in the heating system supply temperature at the nighttime.

The course of changes in the concentration of carbon dioxide in daytime hours was of a polynomial nature, and in the night hours, it was a linear nature of a constant value. This was due to the specificity of the building, where people did not stay in the night.

Similarly, the course of changes in the air relative humidity showed a polynomial nature in daytime and linear at night with almost constant value. 


\section{Conclusion}

The subject of the research was the analysis of the microclimate in rooms in nursery building. There were observed the fungi. The most of them occurred in the playroom at the incubation temperature equal to $37{ }^{\circ} \mathrm{C}$, i.e., the temperature inside the human body. There were observed, at the incubation temperature of $25^{\circ} \mathrm{C}$, only two species of fungi: Candida sp. and Penicillium sp. in this room. It is the temperature maintained in the rooms of the analyzed object; therefore, there is the probability of development of these fungi in the building. The cloakroom is another room in which different species of fungi were detected. None of the observed fungi poses a threat to the lives of the people staying in them, but they can cause allergies and asthma; therefore, it is reasonable to keep the internal temperature at a lower level, while maintaining the regulations in force in the country. At the same time, regarding reference objects, equipped with the passive stack ventilation, the microclimate in the analyzed building was free from the fungi yeast-like fung $i$ and $T$. viride, which occurred in the reference rooms.

The analysis of the carbon dioxide concentration showed a good dilution of pollutants in the building. The parameter value only in the cloakroom slightly exceeded $700 \mathrm{ppm}$ above the concentration in the outdoor air. The lowest observed values occurred in the bedroom, which, also in terms of microbiology, was the cleanest room.

The relative humidity of the internal air was maintained at a level that did not favor the development of fungi.

To sum up, used mechanical ventilation system was sufficient to maintain proper microclimate conditions. The carbon dioxide pollution was sufficiently diluted. The microbiological contamination did not pose a threat to children's health and lives. However, it would be appropriate to keep the air temperature at a lower level.

Acknowledgments This work was not supported by funding institution. We would like to thank the workers of the nurseries for making the buildings available for research.

\section{Compliance with ethical standards}

Conflict of interest The authors declare that there is no conflict of interest.

OpenAccess This article is distributed under the terms of the Creative Commons Attribution 4.0 International License (http://creativeco mmons.org/licenses/by/4.0/), which permits unrestricted use, distribution, and reproduction in any medium, provided you give appropriate credit to the original author(s) and the source, provide a link to the Creative Commons license, and indicate if changes were made.

\section{References}

ASHRAE (2016) Ventilation for acceptable indoor air quality. The American Society of Heating, Refrigerating and Air-Conditioning Engineers (ANSI/ASHRAE Standard 62.1-2016)
Bakó-Biró Z, Clements-Croome DJ, Kochhar N, Awbi HB, Williams MJ (2012) Ventilation rates in schools and pupils' performance. Build Environ 48:215-223

Fisk WJ, Lei-Gomez Q, Mendell MJ (2007) Meta-analyses of the associations of respiratory health effects with dampness and mold in homes. Indoor Air 17:284-296

Garrett MH, Rayment PR, Hooper MA, Abramson MJ, Hooper BM (1998) Indoor airborne fungal spores, house dampness and associations with environmental factors and respiratory health in children. Clin Exp Allergy 28(4):459-467

Górny RL (2005) Submicron particles of fungi and bacteria-a new threat to the interior environment. Internal air quality problems in Poland. Warsaw, pp 25-40 (in Polish)

Huttunen K, Pelkonen J, Nielsen KF, Nuutinen U, Jussila J, Hirvonen MR (2004) Synergistic interaction in simultaneous exposure to Streptomyces californicus and Stachybotrys chartarum. Environ Health Perspect 112:659-665

Khurshid S, Siegel JA, Kinney KA (2014) Indoor particulate reactive oxygen species concentrations. Environ Res 132:46-53

Koruba D, Zender-Świercz E, Piotrowski J, Orman Ł, Telejko M (2014) An attempt to improve the quality of indoor air in kindergarten. Constr Archit 13(4):7-13 (in Polish)

Mendell MJ, Mirer AG, Cheung K, Tong M, Douwess J (2011) Respiratory and allergic health effects of dampness, mold and dampnessrelated agents: a review of the epidemiologic evidence. Environ Health Perspect 119:748-756

Miśkiewicz P (2005) The quality of the internal air - the perspective of the World Health Organization. Internal air quality problems in Poland. Warsaw, pp 137-140 (in Polish)

Nantka MB (2006) Indoor conditions in Silesian buildings with natural ventilation. Indoor Built Environ 15(6):571-582. https://doi. org/10.1177/1420326X06073197

Penttinen P, Pelkonen J, Huttunen K, Hirvonen MR (2006) Cocultivation of Streptomyces californicus and Stachybotrys chartarum stimulates the production of cytostatic compound(s) with immunotoxic properties. Toxicol Appl Pharmacol 217:342-351

Samson RA, Flannigan B, Flannigan ME, Verhoeff AP, Adan OCG, Hoekstra ES (1994) Recommendations. In: Samson RA, Flannigan BB (eds) Health implications of fungi in indoor environments (air quality monographs), vol 2. Elsevier, Amsterdam, pp 529-538

Schwartz J (2004) Air pollution and children's health. Pediatrics 113(3):1037-1043

Sowa J (2017) The quality of the air in the interior as an element that influences the comfort of work. Circulations 37:32-33 (in Polish)

Telejko M, Zender-Świercz E (2016) Attempt to improve indoor air quality in kindergartens. Procedia Eng 161:1704-1709. https:// doi.org/10.1016/j.proeng.2016.08.649

Telejko M, Zender-Świercz E (2017) An attempt to improve air quality in primary schools. In: Proceedings of 10th international conference: environmental engineering. https://doi.org/10.3846/envir o.2017.051

Tuomi T, Reijula K, Johnsson T, Hemminki K, Hintikka EL, Lindroos O, Kalso S, Koukila-Kahkola P, Mussalo-Rauhamaa H, Haahtela $\mathrm{T}$ (2000) Mycotoxins in crude building materials from waterdamaged buildings. Appl Environ Microbiol 66:1899-1904

Wargocki P, Wyon DP (2006) Research report on effects of HVAC on student performance. ASHRAE J 48:22-28

WHO (2004) Regional Office for Europe Children's Environment and Health Action Plan World Health Organization, Copenhagen

Zhang X, Wargocki P, Lian Z, Thyregod C (2017) Effects of exposure to carbon dioxide and bioeffluents on perceived air quality, self-assessed acute health symptoms and cognitive performance. Indoor Air 27(1):47-64 